\title{
Agriculture in Pakistan and its Impact on Economy-A Review
}

\author{
Anam Azam ${ }^{1 *}$ and Muhammad Shafique ${ }^{2}$ \\ ${ }^{1}$ Beijing Language and Culture University, China \\ ${ }^{2}$ Construction Environment Engineering, Korea Institute of Civil Engineering and \\ Building Technology Campus, University of Science and Technology, Korea \\ 1*Anamrafiq95@gmail.com, ${ }^{2}$ shafique@ust.ac.kr,
}

\begin{abstract}
Agriculture is considered the backbone of any economy and it is also the most important sector of Pakistan's economy. The purpose of this research is to analyze the Pakistan's agriculture and its impact on economy. This study also highlights the agricultural challenges and its possible solutions. Time-series data is used in this paper and data is collected from different articles, websites and reports. The agriculture sectors i.e. major and minor crops, fruits, livestock, fisheries and forestry are studied in this research paper. There is some agriculture problems i.e.; limited water, poor management, natural calamities and others which have negative impact on Pakistan's economy. The findings shows that due to agriculture problems there is fluctuations in Pakistan's economic growth (GDP) thus, Pakistan's economic growth is going to slowdown. Total factor of production is also going to slow down due to these instabilities.
\end{abstract}

Keywords: Agriculture, Economy, Major Crops, Fruits, Livestock

\section{Introduction}

Agriculture plays a crucial role in the economies of least developing countries (LDC) like Pakistan. Agriculture is a fundamental part of Pakistan's economy. Pakistan's agricultural contribution to Gross Domestic Product GDP is $21 \%$ with an annual growth of $2.7 \%$ [1]. Agriculture provides an employment opportunities for $44 \%$ of the labor force and $62 \%$ of the rural population depend upon this sector for their livelihood. Agriculture is an important sector in which our modes of life and business innovativeness combine together. It has manifold roles in the economy of any nation and these roles including food security, poverty reduction, industrial revolution and economic growth especially in developing countries [2]. Agriculture is that where basic and economic reproductions intertwine with each other. The significance of agriculture can be seen in economic sector from three perspectives, 1) to provide food to nation and filaments for domestic industry; 2) means of earnings foreign exchange; and 3) provide goods and services in domestic industries and international market. The Pakistan's total area is $796,095 \mathrm{~km}^{2}$, about 22 million are cultivated and 8.3 million are non-cultivated land. Pakistan blessed with natural resources and covered many ecological and climatic zones. The major natural resources of Pakistan are arable land and water [3]. According to Federal Bureau of Statistic 2015-2016, this sector supports three quarters of country's population, employs $42.3 \%$ (36.2\% male and $74.5 \%$ female) of labor force, and provides a huge share of foreign exchange earnings.

Pakistan is a diverse country in its geography and wildlife. Climate alters from northern arid high desert 5000 meter altitude to southern coastal sub-tropical. Pakistan is semi-industrialized economy with well integrated agricultural sector. Only 21.2 million hectares are cultivated from total area of 79.6 million hectares. Cropped area forms 23.8

${ }^{*}$ Corresponding Author 
million hectares and forests constitute 4.21 million hectares. Almost $80 \%$ of cultivated area is irrigated [4]. The country has world's biggest adjoining irrigation system. Pakistan is one of the largest producers of wheat, cotton, sugarcane, mango, dates, oranges and rice in the world. Major crops (wheat, cotton, rice and sugar cane) provide $6.5 \%$ whereas minor crops $2.3 \%$ of the country are GDP. Fisheries and forestry add $0.4 \%$ and $0.2 \%$ to the GDP respectively. Despite its remarkable and growing agricultural production, the country is striving with huge levels of food insecurity. According to World Food Program, more than $48 \%$ of the population was struggling with food insecurity [5]. The continuous rise in population and agricultural production is placing high demands of water resources. Most of the water resources of the country are being used by agriculture sector whereas a very small amount is being given for domestic and industrial use. The country is also facing many natural and manmade disasters such as floods, earthquakes, draughts, landslides which are also affecting the agricultural growth on a large-scale. During 2014-15, the agricultural sector manifested a growth of $2.7 \%$ due to positive growth of all agricultural sub sectors e.g. Crops, livestock, and forestry and fishing sectors. Pakistan's major crops production performance was weak as only rice and cotton production showed positive growth whereas other crops like sugarcane, maize and wheat production showed a negative growth against the last years. Vegetables and fruits are also revealed positive growth. The livestock sector which contributes $56.3 \%$ in agriculture showed a positive growth of $4.1 \%$ in 2014-15 with respect to last year growth. The fishing sector which contributes $2.1 \%$ in agricultural value addition also recorded a growth of 5.8 against the last year growth. Forestry sector showed a growth of $3.2 \%$ during the year 2014-15 as compared to the last year negative growth [6]. Table 1 shows the agricultural growth in percentage. This table shows that in 2010-11, major crops contribution to GDP was merely $1.5 \%$ and in $2014-15$ it was negative. Fishing and livestock sectors have negative percentage in 2010-11 and then it increase in next years.

Table 1. Agriculture Growth in \% [7]

\begin{tabular}{|c|c|c|c|c|c|}
\hline Sector & $\mathbf{2 0 1 0 - 1 1}$ & $\mathbf{2 0 1 1 - 1 2}$ & $\mathbf{2 0 1 2 - 1 3}$ & $\mathbf{2 0 1 3 - 1 4}$ & $\mathbf{2 0 1 4 - 1 5}$ \\
\hline Agriculture & 2.0 & 3.6 & 2.7 & 2.7 & 2.53 \\
\hline Major crops & 1.5 & 7.9 & 0.2 & 8 & -0.52 \\
\hline Minor crops & 2.3 & -7.5 & 5.6 & -5.4 & 3.09 \\
\hline Forestry & 4.8 & 1.8 & 6.6 & -6.7 & -10.43 \\
\hline Fishing & -15.2 & 3.8 & 0.7 & 1.0 & 5.75 \\
\hline Livestock & -3.4 & 4 & 3.5 & 2.8 & 3.99 \\
\hline
\end{tabular}

Source: Pakistan Federal Bureau of Statistics

\section{Agriculture and Pakistan's Food System}

Agriculture is an important factor in poverty reduction, improved country's economy. Land and water is important resources for agriculture and food production heavily depend on these resources. Pakistan's population increasing day by day and the demand of food increase every year. Food, fiber and shelter are important sources for economy and these resources increased in every year with increased populations. Approximately, $43 \%$ of wheat and $90 \%$ of rice is produced and consumed in Asia. Globally, the availability of food depends on population growth, climate change, natural disasters, war and civil unrest. When food prices go up due to shortage of food it is hard for poor people to 
access food. According to the report, $47 \%$ of the total population is based on agriculture and $70 \%$ of foreign exchange reserves of Pakistan achieved by this sector. Pakistan's economy, food security and income are heavily dependent on agriculture but these factors are more susceptible by the influence of bad weather conditions i.e. natural disasters. Pakistan's wheat production will plummet about $50 \%$ due to climate change in 2050 and $40 \%$ is supply to home region of the world's population it will come with irresistible penalty. Currently, Pakistan's mango crops deficiently affected due to climate change and this country bear loss millions of dollars. Therefore, Pakistan must safe the agriculture sectors because it influences the food production [8]. In Pakistan the performance of agriculture is going to low due to hoary technology, Poor management, lack of investment in productions, pests and livestock diseases problems and financial issues disturb the agricultural economy, Hence, Pakistan's agricultural growth is low. Pakistan's food system is insecure, poverty and limited food is available in this country. It is estimated that $1 / 3$ of the population live under the poverty line. In rural areas food poverty is higher about 35\% and in urban areas 26\%. The big issue in Pakistan is the shortage supply of food in rural and urban areas, so Government needs to overcome these problems.

\section{Crops Situation}

Pakistan's agriculture is based on major crops e.g. wheat, rice, sugarcane, cotton and maize which account for almost $24 \%$ of the value added in overall agriculture and $4.67 \%$ of the GDP. Minor crops includes Bajra, Jowar, mash and gram etc., which accounts for $11.36 \%$ of the value added in overall agriculture and $2.25 \%$ of GDP. Livestock contributes $58.55 \%$ to agricultural value addition and $11.61 \%$ to GDP. Forestry contributes $2.06 \%$ to the agriculture vale addition and $0.41 \%$ to the GDP. Fishing adds $2.17 \%$ to overall agriculture and $0.43 \%$ to the GDP.

\section{A) Major Crops}

\section{i) Wheat}

Wheat is the most widely demanded food grain crop of the world. It is the largest grain crop and main country's staple food. Its contribution to GDP is $3.1 \%$ and $14.4 \%$ to the value added in agriculture. The size of the wheat crop is roughly estimated that it increase by $11.7 \%$. Wheat is grown in wide range of area and the climate for wheat is between the latitudes of $\left(30^{\circ}\right.$ to $\left.60^{\circ} \mathrm{N}\right)$ and $\left(27^{\circ}\right.$ to $\left.40^{\circ} \mathrm{S}\right)$. Wheat is grown from aquatic level to more than 3000 m.a.s.i in elevation. The best growing temperature for wheat is about $25^{\circ} \mathrm{C}$, availability of minimum growth temperature of $\left(3^{\circ} \mathrm{C}\right.$ to $\left.4^{\circ} \mathrm{C}\right)$ and maximum growth temperature of $\left(30^{\circ} \mathrm{C}\right.$ to $\left.32^{\circ} \mathrm{C}\right)$ respectively. Wheat is grown in large range areas, where drizzle range from $(250$ to $170 \mathrm{~mm})$ and modified a large range of moisture conditions. Pakistan is the $10^{\text {th }}$ largest wheat-producer country, in terms of total production, area and yield per acres in the world. In Pakistan the average per capita consumption of wheat is about $125 \mathrm{~kg} / \mathrm{year}$ and $60 \%$ of the daily food of common man. Wheat is the crucial food of the population and it occupies a central position in agricultural policies of the government [9].

\section{ii) Rice}

Rice is a most important food staple and cash crop of Pakistan. Rice is the $2^{\text {nd }}$ food staple crop of Pakistan after Wheat and major source of foreign exchange earning product after cotton. Rice has a share of $0.6 \%$ in GDP and accounts for $3.1 \%$ in the value added in agriculture.

Rice is grown under miscellaneous climatic and better soil conditions in Pakistan. Pakistan is also famous for basmati and non-basmati with long grain rice which is divided into four ecological zones. Basmati rice prevails in traditional rice in Punjab area (Zone 
II), in Swat (Zone I), at high altitude rice are grown, in Sindh (Zone III) and in Baluchistan (Zone IV) as shown in Figure 1.

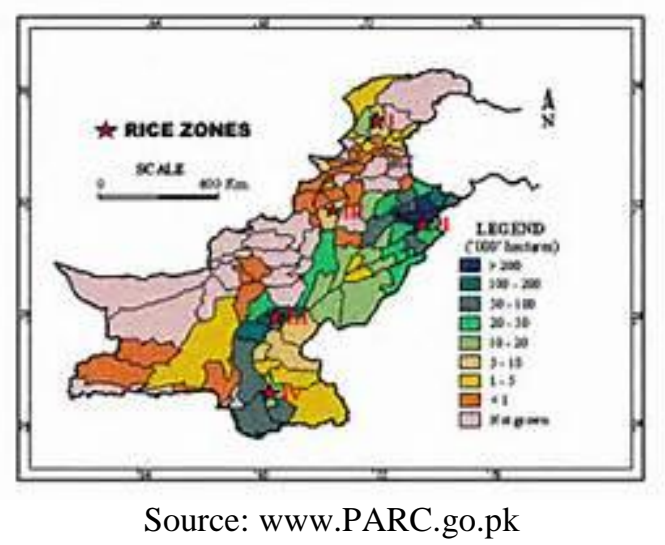

Figure 1. Pakistan's Rice Zones [9]

This Figure 1 shows that Zone I consist of northern mountain areas in flat valleys where rice grown in short duration with cold tolerant varieties. Zone II is lies between two river Ravi and Chenab in Punjab area with sub-tropical climate having fine grain fragrant varieties. Zone III is huge area situated on west bank of river Indus with humid climate and Zone IV is situated on Indus Delta with arid tropical climate. Pakistan is the $4^{\text {th }}$ largest producer of the rice in the World. It constitutes approximately $6.7 \%$ in the value added of agriculture and 1.3\%-1.6\% to GDP. Rice is grown in Khraif (summer) season and harvested period is October-Dec. In Pakistan the temperature for rice is range between $\left(20^{\circ}\right.$ to $\left.30^{\circ}\right)$ and rainfall between $100 \mathrm{~cm}$ to $200 \mathrm{~cm}$. Rice crop depend on rainfall but continuously rain damage the crop production in Pakistan. Rice is cultivated during kharif season but small share of rice is sown in Rabi/summer season.

\section{iii) Cotton}

Cotton is the most important cash and fiber crop of Pakistan. Pakistan is the $4^{\text {th }}$ largest producer and $3^{\text {rd }}$ largest consumer of cotton in the world. Pakistan's cotton industry is an important part of the economy. It plays a major role in foreign exchange earning of the country. It constitutes $55 \%$ to the means of earning, $8.2 \%$ of the value added and $2 \%$ of GDP of the country. Cotton is based on textile and cloth, its constitute $46 \%$ of the total manufacturing and $40 \%$ of the employment. Pakistan is the third largest exporter of the raw cotton and $9 \%$ of the global textile industry share. Cotton is sown in tropical and subtropical areas; the temperature for cotton crop is required $\left(21^{\circ} \mathrm{C}\right.$ to $\left.30^{\circ} \mathrm{C}\right)$ and rainfall of (50-100) $\mathrm{cm}$ in Pakistan.

\section{iv)Sugarcane}

Sugarcane is also high value cash crop and vital for sugar related industries. It has significant effect for national economy of the country. Sugarcane is the crucial source of sugar in Asia and Europe. Generally, it is grown in the tropical and subtropical of the southern fraction because it requires a wide range of climate. Sugarcane is an important cash crop in Pakistan and in several countries of the word. It is the $2^{\text {nd }}$ largest cash crop of Pakistan and added around 3.6\% of Gross Domestic Production GDP [10]. Pakistan is the $5^{\text {th }}$ largest producer of the sugarcane in the world. Pakistan is geographically based in subtropical barren zone and situated (between latitude of $25^{\circ}$ and $36^{\circ} \mathrm{N}$ ) and (longitudes of $61^{\circ}$ to $\left.75^{\circ}\right) \mathrm{E}$ in the Western Zone of South Asia. [11]. Pakistan's climate is hot and 
semi-humid which is more favorable for sugarcane crop, but the growth of sugarcane crop stops or crimp during winter season. Generally, Pakistan's climate is more favorable for the crops productivity through-out the year. But extreme weather conditions and limited amount of rainfalls have inverse effect on sugarcane crop production [12]. Sugarcane crop is propagated in fall/autumn and spring season and it takes 12 to 18 months to ripe. Generally, February-March is the planting period this crop.

\section{v)Maize}

Maize is a significant food grain and a lot of products are prepared from it. It contributes $2.2 \%$ to the value added in agriculture and $0.4 \%$ in GDP. Maize (corn) is the most important commercial crop in Pakistan as compared to other food grains. Pakistan is the $4^{\text {th }}$ largest producer of maize. Maize is sown under diverse climatic and soil conditions and Kharif (monsoon) season is suitable for crop. Maize is grown in warm season, grows from sea level to $3000 \mathrm{M}$ height and the temperature for this crop is available from $\left(21^{\circ} \mathrm{C}\right.$ to $27^{\circ} \mathrm{C}$ ), but it can bear high temperature about $35^{\circ} \mathrm{C}$. The rainfall need for crop is $50-100$ $\mathrm{cm}$ and it cannot be grown in more than $100 \mathrm{~cm}$ rainfall areas. Maize food grain is not only for human but also used for animal feed, for livestock as well as for poultry and oil production. The area, production and yield of major crops are given in Table 2. This table shows that in 2015-16, the production of cotton decreased by 1712 MT.

\section{B) Minor Crops}

The production of Jawar and Bajira crops has demonstrated positive growth of $40.0 \%$ in 2015-16, whereas gram crop has demonstrated a decline in production in last few years because mostly Pakistan's minor crops are heavily dependent on rains. The Barley, Mustard and Rapeseed also showed in a decline by 3.2\% of production in current year of 2015-16 as compared to last year. This decrease in production is due to decrease in area cultivated. The area and production of Tobacco is the same as last year there is no change in this crop. During the year 2015-16, the production of potatoes, chilies and onions enriched positively with a growth of $3.4 \%, 2.1 \%$ and $0.2 \%$ respectively, as compared to the last year. These minor crops upsurge due to increase in the cultivated area. Though, the production of masoor (lentil), mash and moong dwindled by $4.4 \%, 15.6 \%$ and $0.8 \%$. The area and production of minor crops are given in Table 3 . This table shows that some minor crops have negative $\%$ and others have positive $\%$ of production.

\section{Fruits}

\section{A) Fruits}

\section{i) Mango}

Mango is one the most enticing, hot and steamy fruit in all over the world. Mango is called "king of fruits" in worldwide and it has different varieties with different colors, shapes and size. Pakistan is the $4^{\text {th }}$ largest producers of mangoes in the world. In 2011-12, Pakistan produce mango 1.78 million. Mangoes were exported 0.134 million tones and their revenue was $\$ 38$ million [13]. In 2016, the production of mangoes is expected to increase by $40 \%$ against the last year [14]. Pakistan exports mango to UAE, Europe, and Saudi Arabia, Hong Kong, and Canada. The total production of mango was 1.8 million tons per year in 2014. If Pakistan uses modern technology and storage facilities they can increase its export. Currently, china demanded 50,000 tons of mangoes and Pakistan export only 20,000 tons due to some problems [15]. Pakistan is still facing challenges during export of mangos to international markets. Pakistan is an agricultural country but there is some issues i.e. traditional technology, lack of storage facilities, improper management, bad fruit harvesting, poor grading and packing these are some issues that 
become the cause of low export in Pakistan. Fruit fly is the main problem which makes the poor exports standard. Pakistan should increase the export by maintaining the quality standards, proper grading and packing, and storage facilities [16]. When Pakistani mangos entered into international market they cannot utilize the full potential due to poor infrastructure, lack of traditional marketing practices and advertising strategies [17].

\section{ii) Apple}

Apple is generally known as the "sweet gold" and the most famous fruit around the globe. According to the statistical report, Pakistan was $25^{\text {th }}$ largest producer of apple in the world. During the year of 2013-14, the cultivated area for apple was 110,000 hectares and the production of apple was 556,000 tons. Pakistan has different varieties of apple e.g. Amri, Gacha, Kaja, Kulu, Red delicious, Golden delicious and Kashmiri. Pakistan exports apple to China, India, Iran and Russia and importing partners are Iran, New Zealand, South Africa and Italy.

\section{iii) Orange}

Orange is a fresh fruit and utilized in a huge quantity in the world. Pakistan is counted as $6^{\text {th }}$ largest producer of orange. In 2012, the area and production of orange was 160,000 hectares and 1.5 MMT per annum. During 2013-14, Pakistan exported 40,500 tons to Indonesia. Pakistan exports oranges to different countries i.e. UAE, Saudi Arabia and Sri Lanka etc.

\section{iv) Banana}

It is famous fruit in Pakistan and the available area for banana is almost 34,800 hectares with production of 154,800 tons. Pakistan is facing problems to produce banana since post-harvest management and export to international markets due to traditional technology and lack of awareness.

\section{v) Guava}

It is also a popular fruit in Pakistan. Guava is produced under the area of 61.6 thousand hectares and the annual production is 549.5 thousand tons with yield of $8920 \mathrm{~kg}$. The production of guava increased 19,000 tons to 552,000 tons from 1958 to 2008 in Pakistan and its growth rate was 6.9\% annually. Guava is exported to UAE, UK, Saudi Arabia and Qatar whereas, Pakistan exports $26 \%$ guava to Canada. The area and production of fruits are given in Table 4. This table shows that the production of mango increases in every year but in 2013-14, the production of apple shows negative impact.

Table 2. Area, Production and Yield of Major Crops (Million Tons) [17]

\begin{tabular}{|c|c|c|c|c|c|c|c|}
\hline Major Crops & & $\mathbf{2 0 1 0 - 1 1}$ & $\mathbf{2 0 1 1 - 1 2}$ & $\mathbf{2 0 1 2 - 1 3}$ & $\mathbf{2 0 1 3 - 1 4}$ & $\mathbf{2 0 1 4 - 1 5}$ & $\mathbf{2 0 1 5 - 1 6}$ \\
\hline \multirow{5}{*}{ Cotton } & $\begin{array}{c}\text { Area } \\
\text { (000hectares) }\end{array}$ & 2689 & 2835 & 2879 & 2806 & 2961 & 2917 \\
\cline { 2 - 8 } & $\begin{array}{c}\text { Production } \\
\text { (000 bales) }\end{array}$ & 11460 & 13595 & 13031 & 12769 & 13960 & 10074 \\
\cline { 2 - 8 } & $\begin{array}{c}\text { Production } \\
\text { (000 tons) }\end{array}$ & 1949 & 2310 & 2214 & 2170 & 2372 & 1712 \\
\hline
\end{tabular}




\begin{tabular}{|c|c|c|c|c|c|c|c|}
\hline & $\begin{array}{c}\text { Yield } \\
\text { (kgs/hec) }\end{array}$ & 725 & 815 & 769 & 773 & 802 & 587 \\
\hline \multirow{3}{*}{ Sugarcane } & $\begin{array}{c}\text { Area } \\
\text { (000hectares) }\end{array}$ & 988 & 1058 & 1129 & 1173 & 1132 & 1141 \\
\hline & $\begin{array}{l}\text { Production } \\
\text { (000 tons) }\end{array}$ & 55309 & 58397 & 63750 & 67460 & 62826 & 65475 \\
\hline & $\begin{array}{c}\text { Yield } \\
\text { (kgs/hec) }\end{array}$ & 55981 & 55196 & 56466 & 57511 & 55062 & 57840 \\
\hline \multirow{3}{*}{ Rice } & $\begin{array}{c}\text { Area } \\
\text { (000hectares) }\end{array}$ & 2365 & 2571 & 2309 & 2789 & 2891 & 2748 \\
\hline & $\begin{array}{l}\text { Production } \\
\text { (000 tonnes) }\end{array}$ & 4823 & 6160 & 5536 & 6798 & 7003 & 6811 \\
\hline & $\begin{array}{c}\text { Yield } \\
\text { (kgs/hec) }\end{array}$ & 2039 & 2396 & 2398 & 2437 & 2422 & 2479 \\
\hline \multirow{3}{*}{ Wheat } & $\begin{array}{c}\text { Area } \\
\text { (000hectares) }\end{array}$ & 8901 & 8650 & 8660 & 9199 & 9204 & 9260 \\
\hline & $\begin{array}{l}\text { Production } \\
\text { (000 tonnes) }\end{array}$ & 25214 & 23473 & 24211 & 25979 & 25086 & 25482 \\
\hline & $\begin{array}{c}\text { Yield } \\
(\mathrm{kgs} / \mathrm{hec})\end{array}$ & 2833 & 2714 & 2796 & 2824 & 2726 & 2752 \\
\hline \multirow{3}{*}{ Maize } & $\begin{array}{c}\text { Area } \\
\text { (000hectares) }\end{array}$ & 974 & 1087 & 1060 & 1168 & 1142 & 1144 \\
\hline & $\begin{array}{l}\text { Production } \\
\text { (000 tonnes) }\end{array}$ & 3707 & 4338 & 4220 & 4944 & 4937 & 4920 \\
\hline & $\begin{array}{c}\text { Yield } \\
(\mathrm{kgs} / \mathrm{hec})\end{array}$ & 3806 & 3991 & 3981 & 4233 & 4323 & 4301 \\
\hline
\end{tabular}

P: Provisional (Jul-Mar) Source: Pakistan Bureau of Statistics

Table 3. Area and Production of Minor Crops [17]

\begin{tabular}{|c|c|c|c|c|c|c|c|}
\hline \multirow[b]{2}{*}{ Crops } & \multicolumn{2}{|c|}{ 2013-14 } & \multicolumn{2}{|c|}{ 2014-15 } & \multicolumn{2}{|c|}{ 2015-16 } & \multirow[b]{2}{*}{$\begin{array}{l}\% \text { Change } \\
\text { in } \\
\text { Production } \\
\text { over last } \\
\text { year }\end{array}$} \\
\hline & $\begin{array}{c}\text { Area } \\
(000 \\
\text { Hectares })\end{array}$ & $\begin{array}{c}\text { Production } \\
\quad(000 \\
\text { Tonnes })\end{array}$ & $\begin{array}{c}\text { Area } \\
(000 \\
\text { Hectares })\end{array}$ & $\begin{array}{c}\text { Production } \\
\quad(000 \\
\text { Tonnes })\end{array}$ & $\begin{array}{c}\text { Area } \\
(000 \\
\text { Hectares })\end{array}$ & $\begin{array}{c}\text { Production } \\
\quad(000 \\
\text { Tonnes })\end{array}$ & \\
\hline Bajra & 475 & 301 & 462 & 295 & 486 & 299 & 1.4 \\
\hline
\end{tabular}




\begin{tabular}{|c|c|c|c|c|c|c|c|}
\hline Jowar & 198 & 119 & 195 & 115 & 274 & 161 & 40.0 \\
\hline Gram & 950 & 399 & 943 & 379 & 945 & 312 & -17.7 \\
\hline Barley & 71 & 67 & 68 & 63 & 66 & 61 & -3.2 \\
\hline $\begin{array}{c}\text { Rapeseed } \\
\& \\
\text { Mustard }\end{array}$ & 220 & 203 & 214 & 196 & 211 & 194 & -1.0 \\
\hline Tobacco & 49 & 130 & 54 & 120 & 54 & 120 & 0.0 \\
\hline Masoor & 18.2 & 8.6 & 17.7 & 9.0 & 17 & 8.6 & -4.4 \\
\hline Moong & 130.9 & 92.6 & 127.4 & 98.8 & 146.3 & 98.0 & -0.8 \\
\hline Mash & 20.9 & 10.2 & 20.8 & 9.0 & 19.2 & 7.6 & -15.6 \\
\hline Potatoes & 159.8 & 2901.1 & 170.5 & 3997.6 & 176.2 & 4134.6 & 3.4 \\
\hline Onions & 133.9 & 1740.2 & 130.5 & 1671.0 & 130.6 & 1674.6 & 0.2 \\
\hline Chilies & 62.7 & 145.8 & 62.5 & 139.7 & 64.2 & 142.2 & 2.1 \\
\hline
\end{tabular}

P: Provisional (Jul-Mar)

Source: Pakistan Bureau of Statistics

Table 4. Area and Production of Fruits [17]

\begin{tabular}{|c|c|c|c|c|c|c|}
\hline Major Fruits & & $2009-10$ & 2010-11 & 2011-12 & 2012-13 & 2013-14 \\
\hline \multirow{3}{*}{ Mango } & Area (000hectares) & 173.7 & 171.9 & 172.0 & 172.0 & 172.5 \\
\hline & $\begin{array}{l}\text { Production } \\
\text { (000 tones) }\end{array}$ & $1,845.5$ & $1,885.9$ & $1,919.0$ & 1,893 & 1905 \\
\hline & $\begin{array}{c}\text { Yield } \\
(\mathrm{kgs} / \mathrm{hec})\end{array}$ & 10,158 & 10,619 & 10,971 & 11,0006 & 11,043 \\
\hline \multirow[t]{3}{*}{ Apple } & Area (000hectares) & 283.0 & 289.1 & 322.0 & 311 & - \\
\hline & $\begin{array}{l}\text { Production } \\
\text { (000 tones) }\end{array}$ & 1777.0 & 2890.6 & 2203.0 & 1915.0 & - \\
\hline & $\begin{array}{c}\text { Yield } \\
(\mathrm{kgs} / \mathrm{hec})\end{array}$ & 6279.2 & 9998.7 & 6841.6 & 6157.6 & - \\
\hline \multirow[t]{3}{*}{ Orange } & Area (000hectares) & - & 846.5 & 915.0 & 1024.0 & - \\
\hline & $\begin{array}{l}\text { Production } \\
\text { (000 tones) }\end{array}$ & - & 7463.6 & 7922.0 & 10090.0 & - \\
\hline & $\begin{array}{c}\text { Yield } \\
(\mathrm{kgs} / \mathrm{hec})\end{array}$ & - & 8817.1 & 8657.9 & 9683.3 & - \\
\hline \multirow[t]{3}{*}{ Banana } & Area (000hectares) & 770.0 & 830.5 & 797.0 & 776.0 & - \\
\hline & $\begin{array}{l}\text { Production } \\
\text { (000 tones) }\end{array}$ & 26470.0 & 29779.9 & 28455.0 & 26509.0 & - \\
\hline & $\begin{array}{c}\text { Yield } \\
\text { (kgs/hec) }\end{array}$ & 34376.0 & 35859.5 & 35702.6 & 34161.1 & - \\
\hline \multirow[t]{3}{*}{ Guava } & Area (000hectares) & 220.0 & 204.0 & 220.0 & 236.0 & - \\
\hline & $\begin{array}{l}\text { Production } \\
\text { (000 tones) }\end{array}$ & 2572.0 & 2246.23 & 2510.0 & 3198.0 & - \\
\hline & $\begin{array}{c}\text { Yield } \\
(\mathrm{kgs} / \mathrm{hec})\end{array}$ & 11690.9 & 12020.3 & 11409.1 & 13550.8 & - \\
\hline
\end{tabular}

Source: Pakistan Bureau of Statistics 


\section{Live Stock and Poultry}

\section{i) Live Stock}

Livestock sector plays a crucial role in agriculture because it leads towards the rural socio-economic development for rural people. Almost 8 million families are attached with livestock and earning 35\% of income from livestock production activities. It is important for the livelihood of rural low income poor people in the country. It is considered the source of cash income and sometimes it considered the only income earning source for the rural people. It can play a big role in poverty alleviation and foreign exchange earnings for the country. Livestock contributed almost $58.6 \%$ to the agriculture value addition and $11.6 \%$ share of total GDP during 2015-2016 as compared to the 56.4\% and $11.7 \%$ during the adjacent last year, respectively. When the population increase, they changes eating patterns, rise in per capita income and export opportunities are ornamental the demand of livestock and its products in the country. This sector production can be further improved by employing modern management practices, artificial insemination services, better medical facilities and better animal breeding practices.

\section{ii) Poultry}

Poultry is one of the booming and vibrant segments of livestock in Pakistan. It creates job opportunities (direct/indirect) for more than 1.5 million people. Recently, a huge investment is being carried out in this sector. Pakistan is the $11^{\text {th }}$ largest poultry producer in the world with production of 1.02 billion broilers yearly. Poultry not only provide balancing force to have a check on the prices of beef and mutton, but also behaving as backbone of agriculture sector because it consumes above 7 million metric tons of agricultural products. Poultry meat is $30 \%$ of the total meat production in the country. This sector displayed a growth of 8 to $10 \%$ yearly, which shows the inherent potential in this sector. The poultry contributes $1.4 \%$ in GDP during 2015-16, whereas it contributed in livestock and agriculture value addition was 11.7 and $6.9 \%$ respectively.

\section{iii) Fisheries}

Fisheries are also considered an important agriculture sector and it is the main source of livelihood for the coastal areas. Its contribution to GDP is although very small but it provides substantial part to the national income through exports earning. A total of 91,965 MT of fish and fish products were exported during 2015-16. Pakistan export fisheries to China, Middle East, Thailand, Malaysia, Sri Lanka and Japan etc. Pakistan exported 99203 MT of fisheries and earned US \$ 253,497 million during the year of 2014-15. This sector can be further improved by using new fishing technologies, development of value added products and improving the socio-economic conditions of fisherman's community.

\section{iv) Forestry}

Forests are the main source for the Pakistan's environment and it creates socioeconomic challenges for next generations. Overall Pakistan forest resources are limited as less than $4 \%$ of land in Pakistan is covered by forests. However, forestry in Pakistan is rich in terms of biodiversity and provides a unique blend of trees, shrub, grass and animal species. The wood obtained from forests in Pakistan is used in many applications like construction (houses, trucks, trains, boats and busses), furniture, village carpentry, match production, fiber board manufacture, and sports goods preparation. Pakistan is also earns from exporting forestry products abroad. The production of meat, milk and forestry is given in Table 5. This table shows that in 2010-11, meat production was 3094 and then it 
increase in every year. Similarly, milk production slightly increases in every year. In 2015-16, fish production decrease by 501.0 MT. In 2010-13, forestry production increase but in next year it shows negative production.

Table 5. Production of Meat (mutton, beef and poultry), Milk, Fish and Forestry Production [17]

\begin{tabular}{|c|c|c|c|c|c|c|}
\hline Production & $\begin{array}{c}\mathbf{2 0 1 0 -} \\
\mathbf{1 1}\end{array}$ & $\begin{array}{c}\mathbf{2 0 1 1 -} \\
\mathbf{1 2}\end{array}$ & $\begin{array}{c}\mathbf{2 0 1 2 -} \\
\mathbf{1 3}\end{array}$ & $\begin{array}{c}\mathbf{2 0 1 3} \\
\mathbf{1 4}\end{array}$ & $\begin{array}{c}\mathbf{2 0 1 4 -} \\
\mathbf{1 5}\end{array}$ & $\mathbf{2 0 1 5 - 1 6}$ \\
\hline $\begin{array}{c}\text { Meat Production } \\
\text { (000tonnes) }\end{array}$ & 3094 & 3232 & 3379 & 3531 & 3696 & 3873 \\
\hline $\begin{array}{c}\text { Milk Production } \\
\text { (000tones) }\end{array}$ & 37475 & 38617 & 39855 & 41133 & 42454 & 43818 \\
\hline $\begin{array}{c}\text { Fish Production } \\
\text { (000tonnes) }\end{array}$ & 699.9 & 724.8 & 728.8 & 735.0 & 765.0 & 501.0 \\
\hline $\begin{array}{c}\text { Forestry Production } \\
\text { (00. }\end{array}$ & 352 & 354 & 354 & - & - & - \\
\hline
\end{tabular}

P: Provisional (Jul-Mar)

Source: Pakistan Bureau of Statistics

\section{Agriculture and Economic Loss}

Mostly agriculture sector is influenced by flood, when flood comes, it damages the major crops i.e., rice, cotton, wheat and sugarcane. Approximately, 1 million crops destroyed due to natural disasters and these disasters not only influenced the farmer's income but also affect the total crops production. In 2014, 250,000 bales of cotton production damaged due to droughts, sugarcane production decline by 726,000 tons and rice production deteriorated by 217,000 tons. Livestock is an agriculture sector and it is an inferior source of income to fulfill the domestic demands of food. Domestic food also affected by floods and it is estimated that $37 \%$ of household foods lost due to flood. After the floods, about $62 \%$ of people financially lost and other agriculture sectors i.e., forestry and fishery loss due to flood that is influence on food refuge. In 2014, flood damage the other things i.e., $40 \%$ of market loss, $38 \%$ people have sufficient resources to consume food, 55\% loss of agriculture and 12\% loss of livestock [18]. Currently, floods in Pakistan are becoming the cause of economic loss and damage for people. According to the economic report, in future destruction of crops and agriculture sectors will raised the inflation, destroy the market and industries and imbalance of trade and then Pakistan's economy will fall as compared to other countries. During flood, Pakistan's economy decreased by less work, loss of factories and also natural resources decreased due to flood. In short, flood caused the Pakistan's economic growth slump. Wheat is the most important crops of Pakistan and it was damage during floods in 2010. According to the ministry of food, the loss of wheat in Punjab was 44,896 tons, KPK 80,823, in Sindh 5, 41,696 and Baluchistan was 321,651 acres. In 2010 flood came in Pakistan, it was worst flood in Pakistan's history and it destroy almost a million acres of crops (2.9 billion) of agriculture loss. In 2010 flood destroy 200,000 acres rice, sugarcane and 700,000 acres of cotton.

Climate change also destroyed the agriculture sectors i.e., heavy rains loss 100,000 livestock, 300,000 acres animal fodder and damage wheat about 500,000 metric tons of wheat. In 2014, flood destroyed thousand hectares of wheat even it was ready for harvest. According to the economic report, it is estimated that almost 715,000 Pakistan's people affected owing to flood in each year and their annual loss is US\$2.7 billion. According to the economic report, it is estimated that in future 2.7 million people could be influenced 
by floods and their GDP will decline. Pakistan should protect the forests, environment, develop new policies and build dams in order to reduce the floods. Pakistan's government is planning to diminish the floodwaters.

\section{Issues and Challenges of Agriculture in Pakistan}

Agriculture problems in Pakistan disturb the economic growth, in 1947, the contribution of agriculture towards GDP was 53\% but it fall by $21 \%$ in last year. Pakistan's economy depends on three sectors industry, commerce and agriculture and these sectors are interconnected with each other's. Agriculture effects on these two factors, but it faces many problems. Pakistan received about $90 \%$ to $97 \%$ of light rain during summer season and received very few rains during winter season. Pakistan's total land area is $96.9 \%$ and $3.1 \%$ is consisted on water bodies. Pakistan's total cropped area is 23.04 million hectares, $90 \%$ is for land irrigation and 10\% rain nourished. During 20102011, the total agriculture growth was $1.2 \%$ and the growth of major crops was $4 \%$ due to floods. Pakistan is a developing country and with huge population it is also facing water and energy shortage. Furthermore, food inflation increased by $26 \%$ during 2010. Pakistan is an agriculture country but unfortunately it has no modern ways of irrigation and modern techniques; however much of water lost due to leaching and fading. Furthermore, in Pakistan negligence of water leads towards salinity and water logging. There are many agriculture problems in Pakistan. There are some agriculture problems which disturb the Pakistan's economy are as below:

\section{i) Irrigation Problems}

In Pakistan water wastage is lofty and people use antiquated techniques of flood irrigation in which wastage of water is almost 50 to $60 \%$. Developed countries use seep irrigation system to safe the water, however this system not only safe the water but also provide the water according to the requirement of plantations. Unfortunately, shortage of water becomes main issue in this country and the construction of dams has been stopped after two dams. Agriculture is depending on water but in Pakistan there is shortage of water and it is not available according to the needs of plants. Lack of water can destroy the crops and provide less production. In 1960, Indus basin treaty tries to stop the water tank on the channels which were flowing to Pakistan. In Pakistan recently water cannel is not efficiently used for irrigation system and it is recorded that almost 25\%-35\% loss of water in fields. Mostly farmer use tube well water due to the shortage of cannel water and this water is briny which is dangerous for crops and increased soil salinity problems.

\section{ii) Insufficient Infrastructure}

Mostly crops are cultivated in rural areas but in village road conditions are bad and people also face lack of granule issues. In rural areas there is poor infrastructure i.e. insufficient transportation, shortage of electricity, uneducated people, lack of storage facilities and sanitation and health problems, these issues create disturbance in the growth of agriculture. Mostly farmers faced difficulties when they transport fruits and vegetables to market due to poor road conditions and $3 / 4$ of electricity is available for rural people. The storage grain is not good therefore, it damages the crops and also farmer impermanent stored crops which give scarce defense. The crops damaged due to insufficient aeration, high temperature and humidity, shortage of spray and fumigation. The result is that increased bug and bird infectivity. Mostly farmer, labor, and occupant are illiterate and untrained to increase the production and they are not familiar the latest technology. As well as, Farmers health condition is improper due to poverty and their income is very low. According to economic survey, Pakistan's literacy rate in rural areas is $49.2 \%$ and in urban areas is $73.2 \%$ [19]. 


\section{iii) Salinity and Water Logging}

Salinity and water logging is a small problems in agriculture salt appeared on the exterior of land and automatically it affect the crops. It affects the land about 0.10 million per year and it is not only effect on land but also give less production. Mostly cultivated lands in rural area become fatality of this dangerous disease due to the shortage of cannel water. It is estimated that in Pakistan 25\% of area is affected form salinity and water logging.

\section{iv) Traditional Methods of Farming}

Pakistan's famers use traditional methods of farming because they are illiterate. In some areas automation is increasing but some areas old method is used for production. These old techniques decrease the production and therefore the competition level is low in international market. The average crop in Pakistan is just $1 / 4^{\text {th }}$ and low yield per hectare due to old machines in Pakistan.

\section{v) Insufficient Supply of Agriculture Inputs}

The supply of advanced agriculture inputs i.e. compound fertilizers, bug killers, latest mechanism, high yielding variety (HVY) grains etc. these are costly, rough and unsatisfactory in Pakistan. Only 10 units of fertilizers produce in Pakistan. High yielding variety (HYV) seeds are not available so farmer use low quality of seeds in farms to increase production.

\section{vi) Lack of Cultivated Area}

Approximately, Pakistan's total area is 79.6 million and only 23.7 million hectares area is used for farming. However, 8 million hectares area is inactive and not used for agriculture due to land holdings. Landholdings are divided into small parts because of enormous population and land division according to the law of heritage. Moreover, rich farmer holds only 2 hectares of area for cultivation and they use modern technology in their farming.

\section{vii) Financial Condition of Farmers}

Pakistan's farmer are financially weak and poor they born in liability, grow in debt and dies in debt. Mostly 57.4\% farmer adopts feudalism without any charges [20]. Moreover, there is lack of credit facilities for farmers. So, credit facilities are not easily available for them and 50.8\% farmer suffered from loan. The interest rate is high and loan is not available on time. The market prices of agriculture goods remain unstable therefore, farmer cannot get reward due to less and spoiled production, so they are miserable. In Pakistan there is joint family system, so it's a big problem in agriculture and their income is not enough to support the big family. However, they could not save for future and invest due to big family.

\section{Recommendations and Solution for Agriculture Problems}

Pakistan should construct dams and barriers over river because floods and heavy rains could damage the agriculture productions.

Mostly farmer are illiterate and untrained in rural areas, so government should open education program centers for farmer and trained them about farming.

There are no price policies for farmers to get reasonable prices in crops so government should maintain logical prices of production to set living standard for farmers. 
Pakistan should invest and use latest machinery to overcome the agricultural problems and in this way they can boost production's quantity and quality.

Agriculture sectors i.e., livestock, fisheries and poultry based on industries so government should recover these sectors. Government should establish research centers to overcome the agriculture problems.

In Pakistan there is no high yield variety of seeds so government should require (HYV) of seeds at low prices. Government should control water logging and salinity issue because it is destroying the crops for it they should repair tube wells and cannels.

Pakistan should improve irrigation system and introduce agriculture zones.

Government should make new policies and programs to overcome the agricultural problems.

\section{Conclusion}

The contribution of agriculture is important for Pakistan's development. Agriculture sector is a spine of economy and it is the main source to develop the economic growth of any country. Agriculture not only fulfills the domestic needs but also provide inputs and outputs for industries i.e., textiles etc. Pakistan is an agrarian country but facing some problem such as low production, food insecurity, inefficient management in agriculture sector, and their agriculture system is complex and therefore their economy is going to slowdown. The competition level in international markets is low due to less production and poor quality. Therefore, government makes some strategies to improve the agriculture system i.e., to make an investment for farmers, increase trade, and use natural resources. Pakistan should improve both public and private sector for the improvement of agriculture system. The use of modern technology is important for agriculture therefore they should use mechanization, well-organized irrigation methods, improve packing and quality, make more dams, introduce agriculture zones and make some other policies. The government should introduce the modern technology in agriculture regions. In rural areas, large lands are more able for production rather than small lands and overcome the feudalism issues. These efficient ways will improve the Pakistan's weak economy.

\section{Acknowledgment}

The authors sincerely thank all of the contributors and reviewers who suggestions made the paper in its recent form.

\section{References}

[1] Govt. of Pakistan, (2004/05), Economic Survey, Ministry of Finance, Islamabad.

[2] Timer, CP (2002). "Agriculture and Economic Development in BL gardener \& GC Rausser (ed), Handbook of agriculture economics, Amsterdam, North Holland, Vol. 2A, pp. 1487-546.

[3] Government of Pakistan, Pakistan Federal Bureau of Statistics, Agriculture Statistics, 2015-16.

[4] Government of Pakistan, Pakistan Bureau of Statistics, Agriculture Statistics, 2011-12.

[5] United Nations World Food Program (WPF), Benin, Fact Sheet 2009.

[6] Government of Pakistan, Pakistan Bureau of Statistics, Labor Force Statistics, 2014-15.

[7] Government of Pakistan, Pakistan Statistical year book, 2011-12, Federal Bureau of Statistics, Agriculture Statistics, Islamabad.

[8] M. Arif, N Khalid. "Agriculture and Food Security in Pakistan". The east. 2007.

[9] Sahid M, (2003). "Wheat in Pakistan". Pakistan agricultural research council. www.PARC.com

[10] Anonymous (2005). "Economic Survey on crop situation". Federal Bureau of statistics. Government of Pakistan. Islamabad: p.10.

[11] Salma S (2012). "Rainfall Trends in different climate Zones of Pakistan". Vole, 9, Issue, 17.

[12] Anonymous (2003). "Sugarcane crop". Food and agriculture Organization (FAO), New York, USA.

[13] Pakistan Fruit and Vegetable Exporters, Importers and Merchant Association (PFVA), 2016

[14] Government of Sindh, Pakistan, Sindh Board of Investment, 2013. Government of Pakistan, Trade Development Authority of Pakistan (TDAP), 2016.

[15] Government of Pakistan, Pakistan Bureau of Statistics, Agriculture Statistics, 2013-14. 
[16] Government of Pakistan, Ministry of National Food Security and Research 2014, Islamabad.

[17] Government of Pakistan, Pakistan Bureau of Statistics, Pakistan Flood Impact Assessment, 2014.

[18] Government of Pakistan, Pakistan Federal Bureau of Statistics 2015, Literacy rate in Pakistan.

[19] United Nations Development Program, Pakistan human development report, 2003.

[20] Rabia Hameed, Muhammad Imran. “Challenges in Pakistan's agriculture”. Business recorder. 2014

\section{Author}

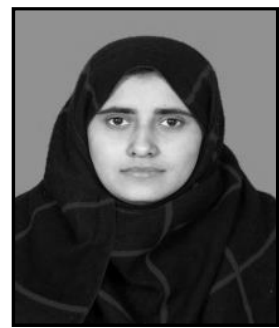

Anam Azam, was born in Gujrat, Pakistan on 12 April 1991. She is currently doing her Master in Economics from Beijing Language and Culture University, Beijing. She has completed her BA in Economics (2010-2012) and MA in Sociology (20122014) from University of Gujrat, Pakistan. Her research interests includes International Economy, Agricultural Economy, Educational Economy. 